\title{
Editorial
}

\section{Brand revelation}

On a cold March morning 1984, the 65year-old President and founder of Wal-Mart, Sam Walton, stepped into a grass skirt, put on a Hawaiian shirt splotched with purple flowers and perched a wreath of flowers on his balding head. He then danced the hula-hula down Wall Street. Half-a-year earlier, he'd sworn to his co-workers that if Wal-Mart's pre-tax profits for the year reached 8 per cent of sales, he'd hula-hula down Wall Street to celebrate. The whole episode was videotaped so it could be shown to the hundreds of thousands of people working in all the WalMart stores. This was the defining moment in the creation of the Wal-Mart brand character. In pulling off this coup de theatre Sam Walton succeeded brilliantly in his goal of 'making our people feel part of a family in which no one is too important or too puffed up to lead a cheer or be the butt of a joke'.

Sam Walton died five years ago, but his magnetic character and his relentless communication of that character as an internal marketing tool, have outlived him. The Wal-Mart credo - accessibility, small town family values, looking for the good in other people - reflects the beliefs and drive of Sam Walton himself and are still the core of the Wal-Mart organisation. The closest equivalent in the $\mathrm{UK}$ is Virgin, where Virgin staff have little difficulty understanding the brand character because it is based on the perceived values and actions of an individual. The question 'what would Richard do in this situation?' is an intuitive touchstone for gauging whether an action is on or offbrand.

The key question for brands that do not possess these sort of charismatic talisman, is how can they create this sort of distinctive brand character that can be intuitively absorbed and understood by employees, the company's suppliers and consumers alike? It is possible to create a character for a brand based on an understanding, derived from both employees and customers, of where the brand is now, where it has come from and where it could go in the future. In doing this it is important to make a distinction between brand personality and brand character. As Stephen Covey highlights in his book, 'The Seven Habits of Highly Successful People', personality implies image consciousness, techniques and quick fixes, while character infers the effort of identifying and integrating certain principles and habits deep within an organisation.

What is the role for brand character? Treating brand character or personality as a separate box on an advertising brief or positioning statement is ludicrous. Especially if we replace the term brand personality with brand character. The brand character is the brand: it is how consumers experience the brand. Whether defining the brand, evaluating its competitors or setting its strategic direction, it is the starting point and the crux.

There are two obvious pitfalls to avoid when defining brand personality or character. First, describing a brand as a string of words - for example, quirky, trustworthy, confident, fun, upbeat, reliable - is, at worst, a list of generics. At best it begins to describe a brand, but it still doesn't really help people to understand or define the special and unique values inherent in the brand or how the brand actually behaves in 
different circumstances. Second, there is the danger of creating an unrealistic superman simply thinking of all the positive traits that the brand would like to have, rather than looking at it as a living and thereby flawed entity. Real people have weaknesses. If a brand profile is credible then it too must have weaknesses. Without weaknesses a brand profile will simply be an optimistic wish list rather than a believable and involving profile.

How can these pitfalls be avoided and brands be defined holistically? The point of defining your brand is to inspire: whether it is staff on the shop floor who need to live the brand every day, an advertising agency with a brief to create outstanding work or a board of directors setting a new strategy. To inspire great service, great advertising or great strategy, it is necessary to create tangible examples of powerful and evocative brand encounters that demonstrate how the brand should behave. The best approach is to create a series of different brand encounters such as:

- a range of adcepts of creative ideas;

- acted out examples of telephone queries and how they are handled;

- acted out customer complaints and how these are dealt with;

- different types of public relations statements;

- different sorts of letters sent to customers;

- a range of different direct mailings.

The key here is to create a number of different versions of the same sort of encounter - adcept, query, complaint, PR, direct mail - each reflecting different type of brand character. Here it is possible to bring in psychometric profiling techniques derived from Neuro Linguistic Programming's Meta Programmes and the MyersBriggs Type Indicator, to define what the brand character actually is, as though it were a real person. It is then up to consumers and employees to choose which type of brand encounter and thereby which brand character is best for their needs. One of the key outputs of this process is a richly draw brand timeline that explains where the brand has come from, where it is today, and where it should go tomorrow.

This approach involves using consumers and employees in interactive workshops to create this brand revelation, thereby bringing together the external and internal perspective.

The arrival of Wal-Mart in the UK, and the nightmares that this has realised among UK retailers, is testimony to the strength of a company founded on a true brand character, even one based on an American concept of a small town, regular guy.

There will always be cynics of this approach. Lucy Kellaway, writing about the subject recently in the Financial Times said, 'Maybe it is just me, but when I am choosing which "brand encounter" I fancy at teatime, I am interested in taste, sweetness, how filling it is ... that kind of thing. Personality just does not come into it.'

But it has been written of Sam Walton that, 'he was a master at getting people to talk. He'd gather everybody together, grab a bag of peanuts, and go into the back of the store. He'd go in front, have everybody sit on the floor, and get down on one knee to talk to them. He'd get down on your level. He'd make them talk about their ideas. He'd look at a person and talk to that person, and the rest of the world would disappear. He'd do whatever it took to draw you out.' Creating this sort of visceral reality and placing it at the heart of the company is the key to creating great brands, with real personality and attitude, that are character-led.

Richard Woods, New Solutions 